\title{
The research of university library faces the society service
}

\author{
$\mathrm{Na} \operatorname{Lin}^{1, a}$ \\ ${ }^{1}$ Jilin Agricultural University, Changchun, Jilin province, China \\ a36670921@qq.com
}

Keywords: Colleges and universities, libraries, social services, research

\begin{abstract}
This paper discusses the mode of socialized service of university library, including: establishing independent information center, and various types of joint cooperation, strengthening the digital library information service and the mobile library push service.
\end{abstract}

\section{Introduction}

University library has rich resources and professional human resources that will be open these resources are the inevitable trend of library development and socialization [1]. Therefore, how to effectively carry out the social information service work of the library in colleges and universities, is the university library and the society should discuss the problem. Since the $1990 \mathrm{~s}$, "university library socialization service" has been incorporated into the library person's field of vision, has done some discussions, but has not been a unified service mode.

At present, compared with the social needs, and theoretical research, China's thousands of colleges and universities socialized service level is very low. In order to effectively solve the asymmetric theory and practice of the reality of the contradiction, actively explore obstacles to promoting the bottleneck of socialized service of university library, and suggests to adopt effective mode to promote socialization of university library service ability, meet the demand of social information, such as problems to be solved [1]. At present, the degree of Academic Libraries in China to carry out social services by local policy guidance, school development, constraints and needs several factors affect the local economic and cultural development, open to varying degrees, the results achieved are not the same. University Library on the road of social services made a bold attempt to vocational Museum and Public Museum in terms of human, financial, material and other full range of tightly integrated, both to meet the university's teaching, research and information needs and completely open to the public.

\section{Independent information center Set-up}

University library socialization service according to their own conditions, the collection resources, human resources, capital and other permission, university libraries can go to the local industrial and commercial sector registered a separate information center, in order to better for social services. Independent information center of the libraries of colleges and universities socialized service pattern, the former passive service to active service, from closed to open services [2]. When establishing independent information center, the university library to the region social economy, science and technology condition and the development trend of the research, master the characteristics of the different social users and potential demand, use of internal and external advanced technology strength, and absorb information collected from all social aspects, especially the use of computer and network communication technology, the method of combining targeted the development of information resources. Independent information center of the libraries of colleges and universities socialized service pattern, at the same time, which is based on the existing information resources of university library, by formulating the abstract of valuable indexes, collect business important information, using the computer retrieval, pass the required documents for social users, market research, refer to the patent information, design the questionnaire, science of social users with file management, data statistical analysis, professional sid service, to provide users with research reports, foreign language 
translation work, information to meet the social demand for all kinds of information is growing by the user.

\section{Library collaboration with each other}

Main service object of the public library is the social public, the public library is the main force of social service. University library has rich resources of manpower and material resources, not only can meet the requirements of the school teachers and students teaching and research services, there is a certain strength and can be directly or indirectly, for the majority of the public service, so that the university library should actively involve in the camp of socialized service, improving social services with grassroots public libraries [2]. Reality, the resources of university library system scale and the quality to some extent is more superiority than other departments and units and other units even dust, however each university library collection resources construction principle and direction is different, even if the same repetitive nature of the colleges and universities still exist resources construction, the digital resources of repeat purchasing is intensified [2]. In terms of the university library, its own resources to meet the university teachers and students, and satisfy the public demand is somewhat "overwhelmed". Through joint collaboration between all types of library can be complementary advantages, enhance the ability of their socialized service, enlarges the scope of available resources for social users, improve the efficiency of information retrieval, the cost saving resources acquisition. Known of university library, therefore, sharing, it is extremely urgent and necessary. University library needs to break the fragmented closed concept, in-depth research institutes library actively, enterprises and institutions library and other university libraries, library, public library and community library of primary and secondary schools, in library in village, village and township, regional combination to establish information network and service system, through the alliance service system, form a rational layout, radiation coverage area wide, diversified service overall force, continuous development and perfect the social service work, achieve complementary resources, resource sharing, inside the area for the reader, provide good services to users in the whole society.

\section{Strengthen the digital information service}

With the computer network technology and the rapid development and popularization of mass giant, the information carrier the information diversity and virtualization, information needs accuracy and timeliness of the way people's self-acquired knowledge, the library has not been completely Tibetan useful in the sense that the previous library, possession of functions have been greatly reduced, then the knowledge network has been unable to measure the space, so the library must change its functions, continuing to explore its survival and development of the road, in order to adapt to the times demand [3]. For the University Library, for its innovation is to expand the functions of education, the quality of education as the main functions of information, knowledge and establish their own image.

The digital information service mode refers to the use of modern technology and equipment of university library, through the network equipment and means to realize the socialization of university library service. The digital information service, can break through the limitation of time and space, more flexible own service for society of university library users. College libraries should seize the the progress of science and technology has brought about great benefits, give full play to the social service function of the library in colleges and universities, strengthen the network construction and network information resources integration of university library [3]. On the one hand, can buy a lot of database, on the other hand, can make use of knowledge resource integration of library science, it collects scattered, disorder of all kinds of information, classify the process integration, making a random disordered information into an orderly, stable, can effectively high-speed access of information resources. , on the basis of digital resources in college libraries should continuously strengthen their own websites construction, through the library website to introduce social users at home and abroad the latest dynamic and relevant information, make social users grasp the initiative information. The university library to strengthen the digital information service mode, can make 
between university library and social users, with other libraries, and more convenient collaboration and communication between various related industries, in the information resources, as well as exchange of service function, truly achieve the purpose of the resource sharing, at the same time also makes the university library socialization service is more feasible.

\section{Using mobile library push service}

Active push service in university library to the social users, can speed up the pace of the socialization of university library service. Actively push service socialization of university library is a flexible way, it is in line with the concept of active service, can organize social service team, through the way of mobile library, users may need to carry on high society resources and the university library professional services personnel, users send books and services to the society [2]. Using mobile library push service of university library, will first user classification society, step by step according to different user types have layers of mobile library services; Secondly the university library to predict different social needs of users, targeted to provide the service. Such as: the university library can send books into the community, to the community of social users promote life, entertainment, health care and other aspects. University library can also send data into the enterprise, the university library collection, development and research of knowledge products sent to the corresponding enterprise, mutual benefit is the enterprise and university library [3].

Active push service is direct, flexible, and many other advantages, for urban and rural areas in the western regions is an efficient way. Because of the western region economic reasons, county and township finance very nervous, most areas have no capacity building your own library, so these areas the demands by the public's knowledge, skills, and a lot of limitations. Through active push service of university library, can regularly or irregularly to social book CD information to meet the needs of users, such as science and technology information in the form of a mobile library passed to them, this kind of service costs low, to overcome the shortage of financial fund.

\section{The social service of the university library mode}

University Library is the Documentation and Information Center of the College, a wide variety of collections, wide range of disciplines, professional, systematic, integrity and usability features. In addition, the University Library as well as some other information agencies do not have documents, such as doctors, masters thesis. High-quality collections not only meet the needs of our students and teachers, but also for social services has created favorable conditions.

The necessity of university library's social service.Government purchase of public services means the government will originally held by the government directly, provide services for social development and people's life matters to have to complete the qualifications of social group or residents, and according to the quantity and quality of service provided by social organizations, according to certain oak must pay the service fee after the assessment, it is a kind of "the government bear, commissions, contract management, assessment to cash" way of the new government to provide public services [4]. Construction of university library has a wealth of information resources, literature also has a considerable scale, advanced technology and equipment and technical means, has trained professional talent team, in order to maximize the use of human resources and information resources of university library, and broaden the service areas, improve service levels, service socialization has become the inevitable trend of college library development, become the trend of social development [3]. But the university library to serve the society must be voluntary, not mandatory. University library is the nature of the thought of the school's teaching and research services, and social service need to pay a large library of manpower and material resources, so no matter from the aspects of human and material resources library will not invest a large energy.

With the speeding up the pace of service-oriented government construction gradually, the government's ruling ability has been reflected in the supply of public service, government support for public cultural services and investment increasing, from the local government and colleges and universities is hope to get more preferential policies and financial support, at the same time, the 
abundant literature information resources in university library and the high quality information service to promote the development of society and culture. Solve the problem of university library service society, therefore, may be considered by the university library to participate in government service delegate or project purchasing, realizes the government, society and win-win situation of university library.

The library services in the community. To develop community culture activities. According to the actual situation of the community, the library to the community residents to carry out various forms of cultural activities, through to the community residents to carry out cultural activities in university library, can meet the needs of the community residents' cultural life, improve the cultural quality of community residents. For government departments to improve the quality of the civic culture provides effective help [4]. Provide training services for community residents. On the one hand is to provide information skills training. According to different information needs community residents, targeted to carry out the community university library reader training, regularly or irregularly to organize all kinds of lectures and training. Through training and study, to enable users to not only master the use of various resources, promote user self-help information service ability, at the same time, to help users understand the rational utilization of network resources related knowledge of law, economics, guide them correctly to obtain the required information. On the other hand is to provide vocational skills training. For re-employment personnel provide employment guidance and advice.

The quality of the university library socialization service guarantee. Purchasing service for the library to face social different fields and different levels of users, the surface is a complex process, but the library has abundant literature information resources, professional services and high quality talent team, it's not difficult to operate [5]. For the government functional departments and user groups, related to the financing and management issues. In order to ensure the quality of purchasing service, the service subject need to be build user demand mechanism, perfecting service supervision mechanism and strengthen the service quality evaluation.

a. Building user demand mechanism. User is the ultimate beneficiaries of information services, but also the service quality of the final decision maker, therefore, to guarantee the quality of purchasing service, the first thing to understand and meet the demand of user information, building user demand mechanism [5]. One is to allow users to fully understand the conditions of library information service supply, such as the library purchase services involving disciplines and fields, external opening time, social user community service scope, etc.; Second is the expression of user times interest demand. According to purchasing service provided by the library of information, the user will give their needs timely and accurate feedback to the library. Three is literature information service of the libraries of reaction mechanism of supply subject to the user demand.

b.Improve service supervision mechanism. Services are two-sided, must be based on mutual trust and cooperation, to ensure quality of service. Library to provide services to purchase department of literature informed management of literature service department, service department after receiving documents, to check the library information provided it fits the agreement requirements, then data for safekeeping service department, ensure the effective use of information and management. The library is open to society readers in lending to ensure that the opening time, readers will also obey the borrowing time limit, the return on time.

c.Strengthen the service quality evaluation. Commissioned by the government functional departments and university library in signing the contract, should have a fair and reasonable, systematic assessment and evaluation criteria, Shan buy to evaluate library provides services on a regular basis, according to the evaluation results, the functions of the government departments should be different economic compensation to the library, such as defaults, warning or to suspend the purchase of the service is put forward [5]. In order to guarantee the accuracy and objectivity of evaluation results of examination assessment team personnel by the government functional departments, social professionals and auspicious body with different user representatives. 


\section{Summary}

In summary, the University Library should adopt a variety of ways and means to provide services to a wide audience, satisfy the information needs of internal and external readers, to achieve the most extensive information resource known to build and share. University Library to make society truly become "learning center", "education center", "information center" and "knowledge centers."

\section{References}

[1] J.L. Sun. Library reform should attach importance to human resource management library, Library Work and Research, 2002, vol. 5, PP.133-135.

[2] J. Xu, Library human resource management library, Information Development and Economy, 2003, vol.2, pp.22-24.

[3] X.K. Fan. The differential management of human resources of library, University library journal, 2003, vol.3, pp. 44-47.

[4] X.P. Luo, Locke for spring. Human capital management present situation and the strategy of library construction, Library Work and Research, 2004, vol.5, pp.31-32.

[5] L.J. Zhang, People-oriented improve library services and management of the library, University library journal, 2004, vol.4, pp.169-171. 